\title{
The Canadian Response to Afghanistan
}

\section{by Jane Thomas}

Afghanistan has produced half the world's refugees and the largest refugee population in the world: about 5.5 million. A refugee population is, of course, problematic in itself; however, it is only a symptom of other problems. "The world's largest refugee population" is indicative of the country-wide nature and severity of the problems inside Afghanistan.

This paper draws attention to the nongovernment response to the Afghan crisis. Given the international humanitarian image which Canadians have, and our track-record demonstrating our capability and willingness to help in crises as well as in longer term development, the non-government organization (NGO) response to Afghanistan is severely abnormal - less than half of one per cent of all financial assistance! Only one Canadian relief agency has been present on the scene! Less than two per cent of Canada's intake of refugees is Afghan! Only one Canadian has been employed to work in Canada on the crises! Maybe twenty Canadians have seen the crisis first hand! None of the agencies which exist solely to educate Canadians about the developing world have programmes on educational material on Afghanistan on a regular basis and most have never included any material. How can this happen when most Canadians know there is a major war and a superpower had invaded? The Afghans are the largest refugee population in the world! How can such an obvious need go unaddressed?

Before attempting to explain why the Canadian response has been so limited, it is relevant to describe my own involvement. In 1984, completely by chance, I was assigned to Pakistan as a leader in the Canada World Youth exchange programme. There, with Pakistani counterparts, we began looking at Pakistan's development history, concepts, problems and successes. Although Afghanistan was not on the CWY agenda, its relevance rapidly became apparent. Further, many Afghans were asking, "Why is it so hard to emigrate to Canada?" I was also "discovering" the whole refugee situation and was shocked. Despite having been involved with a number of Third World agencies back home, learning about different world situations, development issues and social justice, no one had ever mentioned the fact that there were so many. When I went to Pakistan, I wondered why I had never heard of the Afghan refugees.

Seeing the refugee camps spread out as far as the eye could see and for hundreds of kilometres, I began seeking Canadian relief workers to educate me and answer my questions. I could not find any! All officials said, "There are no Canadian relief agencies or Canadians here." I found no evidence of any Canadian help. Then, as now, Canada and Canadians are considered absent.

Back home in Canada, I thought, this cannot be true. I still had certain expectations of Canadian humanitarians. We go out and help everywhere, don't we? Thus began the research now summarized in the boxes. It proves that the officials were not exactly correct. Canadians have helped a little, but very little.

At about the same time I began speaking nationally, with a concentration in Ontario and Alberta. I gave slide/talk presentations at universities and held discussions with numerous Third World social justice and development organizations, church groups, general audiences, the media and so on. As I have continued to study the Afghanistan situation, I made thousands of contacts in Canada attempting to elicit understanding and help. For five years I have also listened to the Canadian perception of what is happening in Afghanistan.

All of my experience made me question whether I should adjust my expectations of Canadian humanitarians downward to be realistic. But I also wanted to change things, inspied every time I saw "global justice" or "social justice" on a letterhead or in a pamphlet.

Generally speaking, I have found that the only place empathy for the Afghans is expressed is in the general public. The least interest and empathy seems to be with the NGOs, and that is odd because only they exist officially to care about such things.
But in all areas of the public and the NGO community, there is an anti-Muslim bias. Information from the Soviet perspective is very common. Except for Afghans in exile in Canada and a handful of others, I have not encountered a single Canadian connected with any NGO who appears to have made an attempt to understand the popular resistance movement - its ideas or ideology. Many apparently have never even grasped that it is a popular resistance movement, and, because the ideas of the resistance are not known, they are assumed to have none.

Only two Canadian organizations, the Afghan Association of Ontario and Human Concern International, have taken a pro-active stance in favour of the resistance and condemned the Soviets and the Kabul regime.

By far, most Canadian NGOs have remained completely silent. Although numerous case examples could be presented, the following four are representative of attitudes revealed in internal or private discussions. It must be emphasized, while remaining unnamed, these cases involve "top of the line", widely known and respected Canadian organizations.

\section{Canadian NGOs}

In 1986, the Canadian Council for International Co-operation, the umbrella group of Canadian non-governmental organizations, published a directory of Canadian NGOs, "engaged in international development". Three hundred and sixteen agencies are listed. This number represents one of the highest per capita number of Third World oriented NGOs in the world.

Agency functions cover a wide range of activities; providing financial, material, technical and personnel assistance in developing countries as well as carrying out social justice, development and public education programming on the various countries in Canada. Solidarity and refugee settlement agencies were not included. 


\section{Case 1}

A few months after my return from Pakistan I was hired as the co-ordinator of a Centre which exists to educate Canadians about Third World problems. The hiring committee told me I was being hired for my administrative skills and to be a spokesperson on Afghanistan. The committee expressed concern that the Centre had developed a quite "far left" image and my speaking on Afghanistan "would lend political balance to the place". When word leaked out amongst a core of the Centre's membership and community that I was being considered for the open position, the protests started. The protests were based solely on one article I had written for the local daily newspaper. It had simply summarized the observations I had made on the Afghan refugees in Pakistan only a few months before. The protesters now blamed the Centre for encouraging "anti-Soviet propaganda", that I was lying and exaggerating about what was happening in Afghanistan. The Board of Directors of the Centre decided to ignore the protests and hired me anyway.

But the outside harassment continued over the following year. Attempts were made each time I gave public presentations to discredit what I said, even though all that I talked about was what I had witnessed. Soviet literature and audio cassettes began appearing on my desk with messages that I "should get to know the truth." Articles or notices I had written for educational purposes would sometimes disappear. Materials on the refugees I placed in the Centre library were quietly

\section{Spokespeople for Afghanistan}

Spokespeople on Afghanistan are exceedingly rare. There are basically only three functioning as such in Canada, the presidents of the Afghan Association of Ontario and the Afghan Medical Relief Organization (AMRO) of Kingston and the author of this paper. Outside of Ontario, there are none, except for a few Afghans in Montreal and Edmonton who have on special occasions spoken out. removed. At social events, there were verbal attacks, almost always, by people from other Third World development agencies who attempted to down play the Afghan situation. "There are no death squads in Afghanistan like there are in El Salvador No chemical weapons are being used. What about the way they treat their women? The number of refugees is just an

\section{NGO Afghan Involvement}

Between 1980 and 1986 a total of seven Canadian NGOs had contributed to Afghan refugees a total of about $\$ 10$ million, but by 1986 only three were still contributing (Salvation Army, the Canadian Red Cross Society and Human Concern International). The Afghanistan Medical Relief Organization (AMRO) of Kingston continued to bring wounded Afghans to Canada for treatment. All other contributors had ceased their support in 1984 or before. Only one of the seven, Human Concern International, had ever been physically present and operating in the refugee camps in Pakistan or inside Afghanistan. The others contributed through partner organizations who were present.

exaggeration by Pakistan to get more ClA help." These were typical remarks. After a year of this discrediting and pressure not to speak, I asked the Board to clarify my mandate. Was I to speak on Afghanistan or not? After a long meeting together with Board and staff, the conclusion was no. "The community around the Centre does not, after all, really understand what the Centre is trying to do". I resigned.

\section{Case 2}

I met with the director of a highly respected NGO known for its public education work on justice and the subject of refugees. Its literature suggests a wideopen mandate for any refugees, but they had done no research or public education work on the Afghans. The subject had never been touched. Although this man had a fair amount of knowledge and sympathy for the Afghans, he explained his agency's rationale for not touching the subject. "We are just convincing the public there isn't a communist under every rock in Central America. If we start talking about Afghanistan, we'll just confuse the public." Later, apparently recognizing a responsibility, they included Afghanistan, amongst other countries, in a new educational kit on the root causes of refugees. While most of the information was fair, a concluding statement included misleading and outrightly false information, and reinforced the negative stereotype of the Afghans and their cause.

\section{Case 3}

I met with the representative of a church-based organization concerned with human rights in Asia. I was told, "No, we've never published anything on Afghanistan." They "would not likely do so either." His rationale was that Amnesty International already was reporting on Afghanistan so he saw no need to. "But", I protested, "you are the specialists in Asia. I know your reputation. A big and important sector of Canadians relies on you to tell them what is happening. They wouldn't necessarily hear from Amnesty. If you don't mention Afghanistan, they could think there are no problems there." Was it religion? This organization reports to Christians, but the Afghans are Muslim. He said no, that was not at all the matter, and pointed out reporting done on other non-Christian situations. The more we discussed the Afghanistan situation, the more it showed why this organization had not provided leadership. His information was an almost word-for-word repeat of the

\section{Canadian-Produced Educational Resources}

Only two Canadian produced resources, which could be considered educational, exist. One is a documentary film produced by Stornoway Productions of Toronto, called "Witnesses: Afghanistan the Untold Story", the second is a small incluion in an NGO kit on the root causes of refugees, which explians why the latter is unsuitable. 
Soviet or pro-Soviet literature which I, too, had read by then; news releases from the Soviet embassy in Ottawa, publications from Izvestia, Progress Books and the newspaper of the Communist Party of Canada, the Tribune.

\section{Case 4}

When the Geneva Accords on Afghanistan were signed the media raved about them as a major UN accomplishment. As Canadians had not followed the talks from the resistance side, the massive injustices, unworkability and devastating effects which the Accords would have, were not widely known or understood. I approached a national umbrella group of some one hundred organizations concerned with refugees world-wide and in Canada. An important function of this group is to watch and analyze political situations as they affect refugees, and mobilize Canadian opinion and responses. $A$ national conference of this group was coming up and it was urgent and timely that the Canadian leaders in refugee causes be informed on the creation of yet more problems for the world's largest refugee population, so that at the very least, blame would not be misplaced.

Anticipating being put on the agenda to speak about the Accords, I approached the president of the organization explaining that the faults of the Accord were caused by the resistance being excluded from the talks and their demands ignored. For years they had demanded that the negotiation process be changed as well to provide a negotiated political (non-military) settlement. The Accords had aban-

\section{Afghan Materials in Resource Centres}

At least 32 Canadian NGO "learner centres" exist specifically and solely to educate Canadians about the developing world and to collect audio-visual and print resources. In these audiovisual collections, there are none on Afghanistan. In eight of these centres almost all print resources on file were from the Soviet perspective. None have included Afghanistan in regular programming and most have never included it once. doned the Afghan people to the regime already committing genocide. At most, I hoped this organization would not be mislead by the media again, condemn the Accords and the Kabul regime and understand why.

The president's response was to give me a newspaper article about an abuse carried out by some Muslim men against a Muslim woman in India. She said, "If this

\section{NGO Afghan Aid}

To put the contribution into context, according to a study conducted by the North/South Institute (Bridges of Hope?), Canadian NGOs raised approximately $\$ 280$ million in 19841985 and that was matched by the government of Canada for a total of $\$ 525$ million. This went to NGO efforts in many countries. In the same year, which co-incidentally is considered to be the most severe year of the war in Afghanistan, the Canadian NGO contribution to the Afghans was a maximum of $\$ 2$ million (part of the above $\$ 10$ million), or less than half of one percent of the total Canadian NGO financial activity.

is anything like what will happen in Afghanistan by 'fundamentalists', I will have nothing to do with them." It apparently had never occurred to her how prejudiced and irrelevant this occurrence was to Afghanistan, two countries away. This president, known to be a humanitarian of the highest order, would never dream of associating events in different Christiandominated countries, say events in El Salvador with those in Peru. And would never judge a whole country by the actions of a few, let alone a few in an entirely different country. Nothing was ever mentioned to the membership. There was, of course, no learning and no condemnation.

These cases are not at all unique. Many others could be cited. They represent part of the vicious circle that has interfered with an appropriate Canadian response. If Canadian humanitarians at the highest level are silent, have a prejudice themselves, make no effort to know the story from the victim's side, have sup- pressed or avoided it or have chosen to know the story from the oppressor's side, then there is no wonder that there is confusion and a lack of public response. Other parts of the vicious circle are:

- Canadian news editors and producers handle the news completely unethically. In 1984 the Kabul regime declared a news black-out, threatening journalists caught reporting independently with imprisonment, execution or both. Since this news black-out everything reported from Kabul is, by law, under government control. But the Canadian news providers fail to mention this restriction and help create the totally distorted picture (that Kabul is the victim instead of the victimizer). Those who oppose the regime have virtually no access to the media. Without an informed and active segment of "watchdogs" in Canada, the media goes uncorrected and the completely distorted picture continues.

- Exceedingly few Canadians have been to Pakistan or Afghanistan to see and hear the resistance's side of the story. Only very few Afghans have been allowed to come to Canada. They are located mainly in one city (Toronto). Only one organization specializes in sponsoring Afghans, the Afghan Association of Ontario, and they sponsor family members only. Major sponsorship problems continue. Not a single organization lobbies on their behalf. Since the number of Afghans is kept low, they have barely an effective

\section{Canadian Immigration Policy: 22 Afghans per Year}

United Nations estimates there are about 5.5 million Afghan refugees in Iran and Pakistan. They are roughly $50 \%$ of the world's refugees and the largest population of refugees in the world. From this number Canada has selected about $2 \%$ of it's own refugee intake. Between 19804and 1988, statistics issued in "Refugee Perspectives" by Employment and Immigration, show that a total of 90,800 refugees have been selected by Canada. One thousand nine hundred and ninety six of those are Afghans. 
voice, which in part answers the original Afghan question: "Why is it so hard to emigrate to Canada?"

- Canadians reject cold war politics, and are unwilling to offend the USSR. Canadians see Afghanistan as a superpower conflict and do not appreciate the fact that, to the Afghans, the conflict is instead a personal and national struggle.

- In Canada there is the perception that Afghanistan is only yet another American-backed war. Thus, associations are made between the Central American Contras and the mujahidin, when there is no resemblance whatsoever.

\section{Volunteers/Staff Overseas}

The Canadian Council fo International Co-operation directory shows Canadian NGOs with a total of at least 7,688 personnel and volunteers overseas. With only one Canadian agency present on the scene - Human Concern International -, exceedingly few Canadians have ever worked in or visited Afghanistan. As HCI employs mainly Afghans, the highest number of Canadians at any given time, working for a Canadian NGO on location, is three. Including Canadian journalists, probably not more than twenty Canadians in total have worked or visited Afghanistan.

- A limited world-view is held by some Canadians, believing that everybody and everything in the world is either pro-Soviet or pro-American, left-wing or right-wing. With this limited view, Afghanistan has been written-off as a right-wing cause. No one seems to imagine or accept other possibilities when the Afghans see their cause as a third way: a state based on Islamic ideals. Add to this the lack of understanding of Islamic movements and Afghanistan is doubly written off. Who are we to think the choice of a nation is unacceptable?

- Public reluctance to do anything which might offend the USSR, blurs functions and influences of humanitarianism, socialism and pro-Sovietism. The "left", in its varying degrees, is in the middle. But "left" in Canada, as far as Afghanistan is concerned, has lost its stated meaning and gone under the Soviet wing. How else can all the materials with a Soviet perspective be explained in the collections of "social justice" organizations? Or why is it that opinions expressed are so often anti-resistance? If, as Canadians prefer to believe, socialism is supposed to mean putting people, their quality of life and justice ahead of everything else (and not blinding and silencing proSovietism), then why has the "left" not followed even one of their leaders or their counterparts in other countries?

The sole, truly commendable thing that Canada has done for the Afghans has been done by the best known socialist and surely one of the most widely respected Canadians, former UN Ambassador, Stephen Lewis. At United Nations annual debates, Lewis dropped all concern for bureaucratic, diplomatic, polite language and scathingly criticized the USSR and Kabul referring to "the evidence that genocide has been committed against the Afghan people by the combined forces of the Democratic Republic of Afghanistan and the Soviet Union". Lewis's speeches made headlines in Canada, but even from within his own fold there was no followup. This is especially enigmatic because European socialists have responded more like Lewis, but have gone even further: taking pro-active stances for the mujahidin.

There is only one clearly identifiable and national sector of Canadians which has demonstrated financial and moral support for the Afghans from the beginning of the war to date: Muslim communities in all provinces. Within their own communi-

\section{Staff in Canada}

One hundred and thirty NGOs employ 6,489 personnel in Canada. When the Canadian Council fo International Co-operation directory was published in 1986 none of the 316 agencies had any staff working on Afghanistan. Not until 1987 was the first Canadian staff member hired to work specifically on Afghanistan in relief, development and public education areas (the author of this paper, by Human Concern). ties there has been a considerable amount of volunteer effort and donations, contributed through the Council of Muslim Communities in Canada and Human Concern International.

Afghanistan is a skeleton in the closet. To a certain extent I sympathize with those leaders who have remained silent. Even saying the word "Afghanistan", in some circles, is met with hostility, suspicion or disparagement.

The Canadian response to Afghanistan is an opportunity to raise questions about ourselves as humanitarians, our influences, conscience and ethics. If we will not acknowledge the faults of a superpower, or both superpowers, can we

\section{Recent Developments}

In 1986, the International Development and Refugee Foundation (Council of Muslim Communities in Canada), through partner organizations stationed in Pakistan, began assisting the Afghans. In 1988 a new organization was formed in Montreal and set up an office in Pakistan to provide assistance: Comité Afghan de Solidarité. In 1988 Care Canada announced plans to begin working with the Afghans, but withdrew the plan in 1989 .

acknowledge our own shortcomings? Still, there is a way to put the Canadian humanitarian dedication to justice, law abiding nature, apparent neutrality on Afghanistan and glasnost to work in possibly the finest act of humanitarianism and justice: begin the process to bring the USSR to trial for crimes against humanity in Afghanistan.

Jane Thomas is the former Director of Public Education for Human Concern International and the author of the booklet "Afghanistan: War and Development" Ottawa: Human Concern International, 1989). Free copies are available from Human Concern International, Box 3984, Station C Ottawa, Canada K1Y 4P2, tel. (613) 2344585. She also compiled the information appearing in the boxes throughout this issue. 